\title{
Presence of Nitrate and Nitrite in Well Water in Mureș County
}

\author{
Fogarasi Erzsébet, Fülöp Ibolya*, Marcu Emanuela, Croitoru Mircea Dumitru \\ Department of Toxicology and Biopharmacy, University of Medicine and Pharmacy Tîrgu Mureș, Romania
}

\begin{abstract}
Objective: One of the most important sources of nitrite and nitrate anions, besides vegetables and meat products, is the drinking water. Presence of nitrite and nitrate in the water in higher concentrations than those set by EFSA ( $0.5 \mathrm{mg} / \mathrm{I}$ nitrite, $50 \mathrm{mg} / \mathrm{l}$ nitrate), may have toxicological significance. A quantitative determination of these ions in samples collected from several pleases from Mureș County was made.

Methods: Ninety-seven well water samples were tested from 12 different places from Mureș County. We used a simple HPLC-UV ion pair method for the determination of nitrite and nitrate concentrations. Sensitivity of the method enables the quantification for concentrations far below the MCL value.

Results: The highest amounts of nitrate and nitrite were measured in Sângeorgiu de Mureș and Cristești. Concentrations of nitrite and nitrate were exceeded in $4.12 \%$ and respectively $44.32 \%$ of the samples.

Conclusions: The high amounts of nitrites and nitrates existing in well water go beyond the expected extent. This pollution can become a health risk since this water is used in human nutrition especially in child nourishment.
\end{abstract}

Keywords: nitrite, nitrate, well water, HPLC

Received: 09 April 2015 / Accepted: 04 June 2015

\section{Introduction}

Nitrate occurs naturally in plans in the nitrogen cycle as a key nutrient. It is used simultaneously with nitrite in the food industry as food preserving additives. Besides these cases it serves as oxidizing agent in production of explosives and for glass making.

Nitrates and nitrites occur in different amount in vegetables, such as dill, lettuce, cabbage, spinach, carrot and beetroot. The highest concentration of nitrate was found in rocket $(>9 \mathrm{~g} / \mathrm{kg})$ and lettuce $(>8 \mathrm{~g} / \mathrm{kg})$ [1]. In agriculture, large amount of inorganic nitrogenous fertilizers and manures are used, which cause the contamination of surface water and groundwater. Therefore, the drinking water can contain a significant amount of NO3- and NO2-, which in some cases can be source of intoxications. The ADI (accepted daily intake) of nitrate is $3.7 \mathrm{mg} / \mathrm{kg} / \mathrm{day}$, and for the more toxic nitrite is $0.07 \mathrm{mg} / \mathrm{kg} /$ day [2].

Nitrate itself is considered of low toxicity, but a part of the ingested nitrate (about 5-8\%) is transformed into nitrite, the more toxic anion, under the influence of bacteria in the mouth or in the stomach. These ions are quickly absorbed and reach the systemic circulation. The nitrite ion can undergo spontaneously a simple one electron reduction to yield NO.

The toxicity of these anions is linked whit three major health problems [3].

First of all nitrite and nitric oxide free radical formed from NO2- can oxidize the ferrous $(\mathrm{Fe} 2+)$ iron to the ferric $(\mathrm{Fe} 3+)$ iron from the hemoglobin structures. The

* Correspondence to: Ibolya Fülöp

E-mail: fulop.ibolya@umftgm.ro methemoglobinemia (metHb) have different clinical features, depending on the blood concentration of metHb. $10-20 \%$ can cause tissue hypoxia, cyanosis; $20-40 \%$ metHb symptoms are headache, tachycardia, and anxiety; $40-60 \%$ metHb signs are lethargy, confusion and respiratory depression; over $60 \%$ metHb may results in coma or even death [4]. Maintaining low levels of metHb is achieved through glutathione reducing capacity, but similarly important is NADPH dependent metHb reductase, which converts metHb back to $\mathrm{Hb}$. The amount of metHb-reductase in the first years of life is lower. Therefore the children up to 3 years, are much more sensitive to the increased amount of nitrite that adults. Fortunately there is no danger of blue baby syndrome for the breastfed infants. Research continues on the effects of nitrates and nitrites during pregnancy. But is recomanded for pregnant women to drink water that does not have high levels of nitrates or nitrites to avoid any inconvenience [5] .

The second damaging effect of the nitrate and the nitrite ion is the genotoxicity. In the stomach nitrite may form the carcinogen $\mathrm{N}$-nitrosamine such as $\mathrm{N}$-nitrosodimethylamine the most frequently nitrosamine formed in the gastric mucosa or in the meats. $\mathrm{N}$-nitrosodimethylamine undergoes CYP oxidation to form an unstable metabolite that releases carbonium cation able to induce DNA damage through a free radical like mechanism. Several studies have been carried out on the correlation of nitrate-nitrite intake and primarily gastric cancer. It was found no significant correlation between gastric cancer and nitrate in drinking-water, but the nitrosamine occurring in the foods was associated with a statistically significant increased risk of stomach cancer [6,7]. 
Production of $\mathrm{NO}$ from food-born nitrate was observed in some experiments $[6,8]$. NO have role in the regulation of vascular tone, neurotransmission, and immunity [9]. The reduce synthesis of NO cause endothelial dysfunction and impaired ventricular contractility in elderly patients, and also can induce the decrease of primary immune protection $[10,11]$. Since NO production from nitrate does not have an enzyme controlled pathway (depends on the nitrate reducing ability of the bacteria in the mouth), an overproduction might appear. The most important negative effect of $\mathrm{NO}$ overproduction is tyrosine nitration in the myocardium [12].

Teratogen effects and thyroid inhibition were also correlated with large intakes of nitrite and nitrate [13].

Because the most important sources of nitrate ion are vegetables and drinking water, the U.S. Environmental Protection Agency (EPA) sets Maximum Contaminant Levels (MCLs) for nitrogen in public drinking water systems $(10 \mathrm{mg} / \mathrm{l}$ for nitrate and $1 \mathrm{mg} / \mathrm{l}$ for nitrite) $[14,15]$. In the EU the guideline values for nitrate and nitrite are $50 \mathrm{mg} / \mathrm{l}$ respectively $0.5 \mathrm{mg} / \mathrm{l}$, to protect against methaemoglobinaemia in bottle-fed infants $[16,17]$. The nitrate and nitrite may occur simultaneously in drinking-water; therefore the sum of the ratios of the concentration $(C)$ of each to its guideline value (GV) should not exceed 1 [18]:

$$
\frac{C_{\text {nitrate }}}{G V_{\text {nitrate }}}+\frac{C_{\text {nitrite }}}{G V_{\text {nitrite }}} \leq 1
$$

Fig. 1. The maximal amount nitrite and nitrate calculating formula

In our work we tried to quantify the nitrate and nitrite amount from the well water in Mures, County.

\section{Methods}

Following chemicals were used: gradient-grade methanol and acetonitrile Merck KgaA, (Germany), tetrabutylammonium (TBA) Merck KgaA, (Germany), sodium nitrate Merck KgaA, (Germany), and sodium nitrite) Merck KgaA, (Germany). Ultra-pure water was obtained using a Mili-Q purification system (Millipore Corporation, USA).
Sample analysis was carried out on a Merck Hitachi L-7000 HPLC system with a DAD detector. A LichroCART 250-

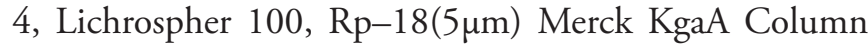
was used for separation of analytes.

Measurements of nitrite and nitrate were done using an RP HPLC-UV ion pair method published in detail elsewhere [19]. Limits of detection are: $2 \mathrm{ng} / \mathrm{ml}$ for nitrite and $5 \mathrm{ng} / \mathrm{ml}$ for nitrate; limits of quantification are: $5 \mathrm{ng} /$ $\mathrm{ml}$ for nitrite and $15 \mathrm{ng} / \mathrm{ml}$ for nitrate. Run time of the method is 12 minutes.

The 97 samples were collected from 12 localities from Mureș County, Romania. Samples were preserved at -20 ${ }^{\circ} \mathrm{C}$ until analysis. After defrosting at room temperature, the samples were injected into the HPLC without dilution.

\section{Results}

Figure 1 shows a typical chromatogram for a well water sample containing bout nitrite and nitrate. The retention time for the nitrite ion is 6.41 minutes and for the nitrate ion is 9.17 minutes (Figure 2).

The nitrate and nitrite contents of well waters are shown in Table I. The values higher than MCL are marked in red.

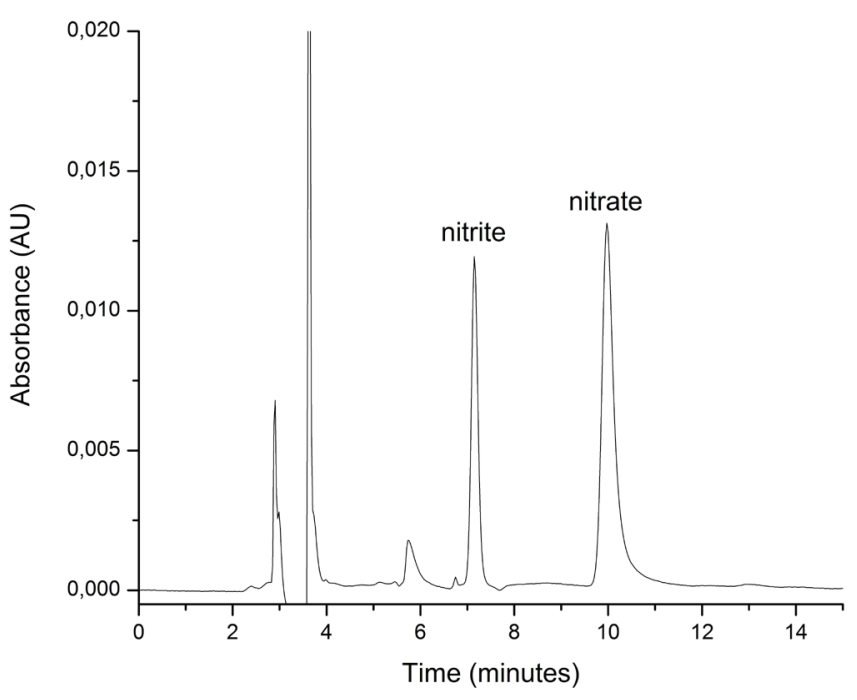

Fig. 2. Typical chromatogram for the nitrite and nitrate

Table I. Nitrite and nitrate concentration from the well water samples

\begin{tabular}{|c|c|c|c|c|c|c|c|}
\hline \multirow{2}{*}{ Location } & \multirow{2}{*}{$\mathrm{N}^{1}$} & \multicolumn{3}{|c|}{ Nitrite $(\mu \mathrm{g} / \mathrm{l})$} & \multicolumn{3}{|c|}{ Nitrate (mg/l) } \\
\hline & & Min. & Max. & Average & Min. & Max. & Average \\
\hline Târgu Mureș & 6 & $\mathrm{BLQ}^{2}$ & $\mathrm{BLQ}^{2}$ & $\mathrm{BLQ}^{2}$ & 0.98 & 124.78 & $63.18 \pm 44.11$ \\
\hline Sângeorgiu de Mureș & 14 & $\mathrm{BLD}^{3}$ & 728.80 & $172.52 \pm 184.52$ & 1.91 & 127.66 & $78.83 \pm 47.44$ \\
\hline Livezeni & 2 & 61.70 & 209.00 & $135.35 \pm 104.15$ & 31.83 & 34.38 & $33.10 \pm 1.80$ \\
\hline Cristești & 30 & $\mathrm{BLD}^{3}$ & 4481.40 & $392.82 \pm 1112.18$ & 3.56 & 169.03 & $67.18 \pm 40.76$ \\
\hline Sâncraiu de Mureș & 7 & $\mathrm{BLD}^{3}$ & 148.80 & $42.72 \pm 51.29$ & 0.35 & 129.66 & $34.10 \pm 55.06$ \\
\hline Sântana de Mureș & 7 & $\mathrm{BLD}^{3}$ & 155.30 & $87.72 \pm 58.96$ & 4.29 & 34.72 & $14.62 \pm 12.05$ \\
\hline Corunca & 3 & $\mathrm{BLD}^{3}$ & 126.40 & $45.33 \pm 70.36$ & 1.00 & 91.23 & $51.11 \pm 45.93$ \\
\hline Sânmărtin & 14 & $\mathrm{BLD}^{3}$ & 182.20 & $58.14 \pm 63.07$ & 0.45 & 240.82 & $68.70 \pm 85.52$ \\
\hline lernut & 9 & $\mathrm{BLD}^{3}$ & 13999.60 & $1963.03 \pm 4643.04$ & 1.49 & 61.24 & $20.27 \pm 18.86$ \\
\hline Cipău & 4 & 36.60 & 150.30 & $75.57 \pm 50.80$ & 0.39 & 97.07 & $45.11 \pm 41.12$ \\
\hline Băla & 7 & 73.20 & 241.10 & $165.07 \pm 69.32$ & 12.91 & 41.34 & $24.20 \pm 12.12$ \\
\hline Gerebeniș & 2 & 124.90 & 247.80 & $186.35 \pm 86.90$ & 34.91 & 49.83 & $42.37 \pm 10.55$ \\
\hline
\end{tabular}


The distribution of the nitrite respectively nitrate concentration in the tested well waters is shown in Figure 1 and 2 . In some cases the nitrite amounts are above the accepted concentration in the EU (4.12\% of the samples) and in one sample the nitrite concentration is fivefold higher than the MCL.

The nitrate levels in the well water are in several cases above MCL. $44.32 \%$ from the collected samples exceed the accepted amount in EU.

\section{Discussion}

The nitrate content of drinking water had extremely large variations for the tested samples. Most of the well water samples contained measurable amounts of nitrite and each sample has nitrate concentration over the LOQ value $(15 \mathrm{ng} / \mathrm{ml})$. In $22 / 93$ samples the nitrite concentration is below the LOQ value $(5 \mathrm{ng} / \mathrm{ml})$ because usually nitrite isn't present in well water.

The largest variations of the nitrite concentration were recorded in the samples collected from Cristești (BLD $4481.40 \mu \mathrm{g} / \mathrm{l})$ and Iernut $(\mathrm{BLD}-13999.60 \mu \mathrm{g} / \mathrm{l})$. The highest variation in the nitrate content have been reported

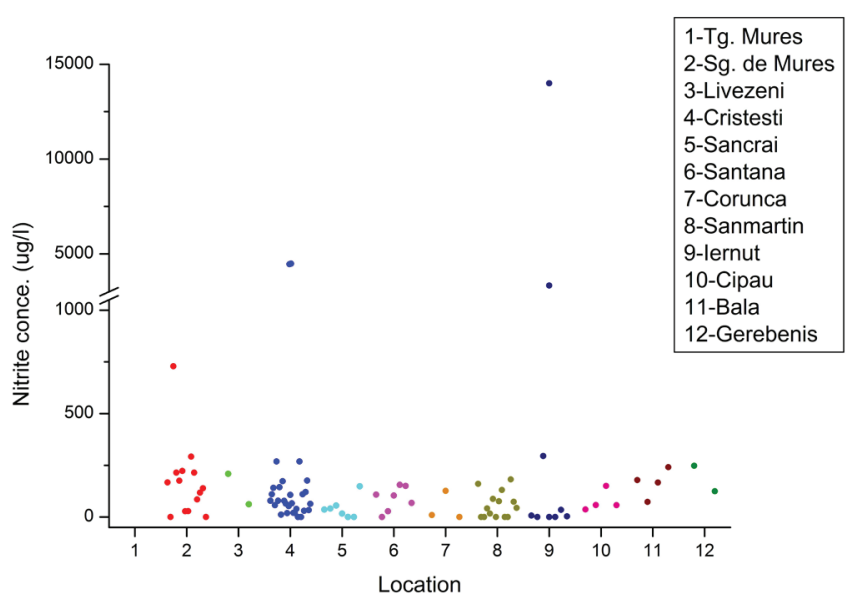

Fig. 3. Distribution of the nitrite in the well water

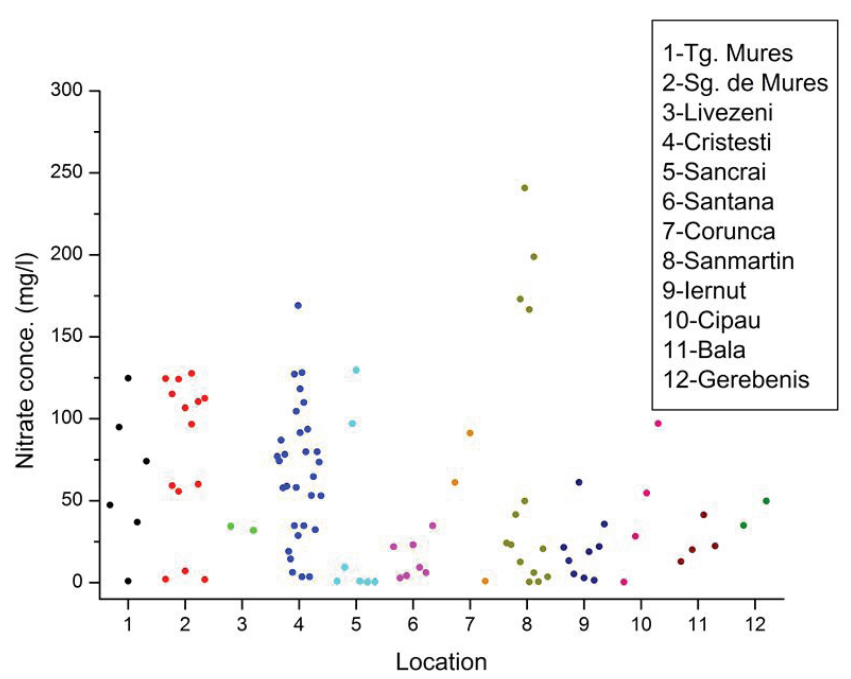

Fig. 4. Distribution of the nitrate in the well water in the case of samples yield from Sânmărtin $(S D \pm 85.52)$ and Sâncraiu de Mureș $(S D \pm 55.06)$. The large variation in the nitrite/nitrate concentration is difficult to be explained since, sometimes, extremely large variations were recorded in well waters obtained from neighboring houses.

The most affected areas are Sângeorgiu de Mureș and Cristești, where the nitrate concentrations pass the MCL in $11 / 14$ samples respectively $21 / 30$ samples.

In several households these water is used in the preparation of foods for adults and children. If a child with a weight of $4 \mathrm{~kg}$ is consuming $600 \mathrm{ml}$ of milk prepared from milk-powder with well water, then the maximum level of nitrite and nitrate in the water, in order to not exceed the ADI, can be $0.46 \mathrm{mg} / \mathrm{l}$ and $24 \mathrm{mg} / \mathrm{l}$, respectively. Sixtyseven samples from 97 showed a higher amount than those calculated to be safe for a $4 \mathrm{~kg}$ child. Therefore, more than half $(69.07 \%)$ from these waters are contraindicated to children feeding.

The general daily water consumption (about 2 1/day) can be also a source of intoxication with nitrate. The ADI of nitrate for an adult with a weight of $60 \mathrm{~kg}$ is $222 \mathrm{mg}$. If these adult drinks 21 of water/day, the nitrate concentration in the water, which allows him to exceed the ADI by consuming water as only nitrate source, is $112 \mathrm{mg} / \mathrm{l}$. In the studied probe in 14 samples the nitrate amount is above $112 \mathrm{mg} / \mathrm{l}$.

\section{Conclusion}

The method used in the determination of concentration of nitrate and nitrite ions is a very sensitive, fast and suitable for measuring low levels of nitrate and nitrite in drinking water samples. In many cases the MCL for nitrate and also for the nitrite ion are exceeded. Considering that in some places well waters are used for the preparation of baby's food, the wells should be periodically checked for the presence of nitrate and nitrite (even if the first measurement shows acceptable values).

\section{Acknowledgement}

This paper is supported by the Sectoral Operational Programme Human Resources Development (SOP HRD), financed from the European Social Fund and by the Romanian Government under the contract number POSDRU/159/1.5/S/133377/

\section{References}

1. Tosun I, Ustun NS. Nitrate content of lettuce grown in the greenhouse. Bull. Environ. Contam. Toxicol. 2004;72:109-113.

2. EFSA (2008) : http://www.efsa.europa.eu/en/efsajournal/pub/689.htm, accessed on 04.2015.

3. Mensinga TT, Speijers GJ, Meulenbelt J. Health implications of exposure to environmental nitrogenous compounds. Toxicol Rev. 2003;22:41-51.

4. Bradberry SM, Aw TC, Williams NR, Vale JA. Occupational methaemoglobinaemia. Occup Environ Med 2001;58:61.

5. Vermont, http://healthvermont.gov/enviro/water/nitrates.aspx, accessed on 04.2015 .

6. FIN, http://fedup.com.au/factsheets/additive-and-natural-chemicalfactsheets/249-252-nitrates-nitrites-and-nitrosamines, accessed on 04.2015. 
7. Poste AE, Grung M, Wright RF. Amines and amine-related compounds in surface waters: a review of sources, concentrations and aquatic toxicity. Sci Total Environ. 2014;481:274-279

8. Bailey SJ, Vanhatalo A, Winyard PG, Jones AM. The nitrate-nitrite-nitric oxide pathway: Its role in human exercise physiology. Eur J Sport Sci. 2012;12:309-320.

9. Radi R. Peroxynitrite, a Stealthy Biological Oxidant. J Biol Chem. 2013;288(37):26464-26472.

10. Gülçin I. Antioxidant activity of food constituents: an overview. Arch Toxicol. 2012;86:345-391.

11. Wu J, Xia S, Kalionis B, Wan W, Sun T. The role of oxidative stress and inflammation in cardiovascular aging. Biomed Res Int. 2014;2014:615312.

12. Pacher P, Beckman JS, Liaudet L. Nitric Oxide and Peroxynitrite in Health and Disease. Physiol Rev. 2007;87:315-424.
13. Croitoru MD, Muntean DL, Fülöp I, Modroiu A. Growing patterns to produce ,nitrate-free' lettuce (Lactuca sativa). Food Addit Contam Part A Chem Anal Control Expo Risk Assess. 2015;32:80-6.

14. EPA, http://water.epa.gov/drink/contaminants/basicinformation/nitrate. cfm, accessed on 04.2015.

15. EPA, http://water.epa.gov/drink/contaminants/basicinformation/nitrite. cfm. accessed on 04.2015.

16. WHO, http://www.who.int/water_sanitation_health/dwq/chemicals/ nitratenitritesum. pdf?ua=1 accessed on 04.2015.

17. EFSA, http://www.efsa.europa.eu/en/efsajournal/doc/1017.pdf, accessed on 04.2015

18. WHO, http://www.who.int/water_sanitation_health/dwq/chemicals/ nitratenitrite_background.pdf?ua=1, accessed on 04.2015 .

19. Croitoru MD, Fülöp I, Tőkés B. Studierea posibilității de formare a monoxidului de azot din nitrone. Rev Med și Farm. 2008;54:171-174. 